\title{
The Constitutional Justice and Protection of the Human Rights (The Constitutional Court of Republic of Macedonia - Dilemmas and Prospects-)
}

\author{
Jelena Trajkovska-Hristovska. Dr. Sci \\ Department of Constitutional Law and Political System \\ Faculty of Law ,Iustinianus Primus”- Skopje, Republic of Macedonia
}

\section{Doi:10.5901/ajis.2015.v4n3s1p384}

Keywords: Law, Human rights, Constitutional court, Control of the Constitutionality of Acts, Judicial review, Constitutional complaint.

\section{The Institute of Judicial Review in the Cradle of History}

An unusual mystique envelops the institute of judicial review, even after its 200 years practicing. The conventional story for its appearing is tied to the case Marbury v. Madison from 1803 and the inventive judgment of Chief Justice Marshall which 'insidiously' usurps the authority of the courts to refuse the application of unconstitutional laws ${ }^{1}$.

It seems that the argumentation of the judgment Marbury v. Madison produces more dilemmas than it solves, regarding the institute judicial review. Thus, Marshall's thesis "It is the courts jurisdiction to say what is law", delicately imposes the question whether that court authorization equally refers to the Constitution.

However, even though it is considered a masterpiece of political maneuvering, the judicial precedent in the case Marbury v. Madison from 1803 is deemed a true beginning of constitutional review in USA and in the whole constitutional history of the modern world.

The development of constitutional review in the European countries completely deviates from the accepted idea and practice of judicial review by the courts on the American continent. The review of the constitutionality of laws in Europe met strong resistance in both the legal and political theory and the practice. The point of view that the passed laws represent the general will, or the expression of the sovereignty of the state, and the limitation of the role of the judges to application of the passed laws in specific cases, leaves the judges without the possibility to further explore the will of the lawmaker and to "diagnose the pathology" of the system. The inability to enact the system of control of constitutionality of law, was frequently argumented with its incompatibility with the principle of people's sovereignty. Until the adopting of the Constitution of Austria in 1920, which implements the control of constitutionality by the Constitutional court, the European countries will remain crucified between the need of an institution for control of constitutionality of law on one side, and the respect of the long constitutional tradition and the thesis of Montesquieu that "the judicial power is no more than the mouth of the law (bouche de la loi)".

\section{On the Constitutional Court of Republic of Macedonia- defender of the Constitutionality and Legality}

The Constitutional judiciary in Republic of Macedonia has nearly a half a century tradition. The first Constitutional court was established in 1963 and represents the most important constitutional novelty and true constitutional achievement. Siljanovska determines that, even though conceived as the bearer of protection of constitutionality and legality, the Constitutional court in reality had marginal position and role'2. Nonetheless, in the conditions in which the other countries with same type of organization of powers, a dominant form of control of constitutionality of law was the self-control model, Republic of Macedonia implemented in its system the first "guardian of constitutionality and legality".

\footnotetext{
${ }^{1}$ The principal postulates on which the argumentation the judgment of John Marshall is based are: Principle of supremacy of the Constitution - The Constitution represents lex superior in relation with the other acts, thus all acts that are not in conformity with it, should not be applied. The nature of the judicial function - If the courts' duty is to determine what is law, in case of mutually contradictory acts, it is the court's duty to apply the supreme (higher) law. Constitutionalism in broad sense - The one sided acceptance of the opinions of the Congress on the validity of acts that are passed by the Congress itself, by the courts, infringes the fundamentals of the written constitutionality. In this manner, the Congress is left without limitations on its powers.

2 Siljanovska-Davkova Gordana. Ustavniot Sud na Republika Makedonija Od Moj Agol. Skopje. 2010. p.14.
} 
The Constitution of Republic of Macedonia from 1991 continues the model of control of constitutionality of law by Constitutional court. The creation of the Macedonian constitution maker, which the system of organization of powers was established on the principle of separation of powers, it seems that it was conditio sine qua non to enable independent position of the Constitutional Court of Republic of Macedonia. The position of the Constitutional Court of Republic of Macedonia is determined with the Constitution of Republic of Macedonia from 1991, in accordance to which the Constitutional court represent an authority out of the regular judiciary, with the function to protect the constitutionality and legality. Even though conceived to represent an authority that would help the transformation from a "dying" state into a legal state and an authority that would defend the supremacy of the Constitution, the constitutional norms leave us with the impression that the Macedonian constitution maker has not fully expressed himself. Namely, the matter that relates to the Constitutional court of Republic of Macedonia is materia constitutionalis, but not materia legis. Opposite to the comparative experiences stated in the literature on the constitutional courts, where the principal questions bound to the composition and jurisdiction of this authority are regulated with the constitutions and further elaborated in a law, the Macedonian constitution maker has excluded this possibility. Today the article 113 of the Constitution provides that the mode of operation and procedures at the Court are determined with an Act by the Court. This provision provides explicit inability to regulate the matter with a law, and the legal consequence from its provision in the text of the Constitution, leaves a possibility for such exceptionally important matter to be regulated only by the Rules of procedure. Thus as Siljanovska ascertains, the Rules of procedure of the Constitutional Court from a procedural act became legal and constitutive $^{3}$. In this context, Treneska shall underline that "the lack of a constitutional grounds for passing a Law for the Constitutional court, leaves to the constitutional judges themselves to decide about many important questions for their own position which is unacceptable since it may lead to infringement of the principle of check and balance."4. Therefore, it is right to determine that such unfortunate constitutional solution leaves room for the biggest fear in the modern constitutionalism to show up in the Republic of Macedonia in the conditions of a new separation of powers, and transformation of the court in a lawmaker or a constitution maker.

It seems that the attempts to find a solution to the so-called problem of counter-majoritarian difficulty, in the case of Republic of Macedonia not only they are not considered, but it appears that it was not even presumed that it may appear when the constitutional norms were created.

The matter for the Constitutional court was not subject of the revision of the Constitution in 2005 when the amendments for the judiciary were passed. Thus the Constitutional court was left without the possibility for a law and legal regulation of the matter.

\section{The Composition of The Constitutional Court of Republic of Macedonia}

The Constitutional court of Republic of Macedonia consists of nine judges with a nine-year term without the right of reelection. In accordance with Amendment XV, the Assembly of Republic of Macedonia elects the judges of the Constitutional court. The Assembly elects six judges with a majority vote from the total number of members of parliament, and three judges are elected with a majority vote of the total number of members of parliament, but there must be a majority from the votes of the total number of members of parliament who belong to communities that are not a majority. Three authorities are included in the procedure for proposing judges of the Constitutional court: the Assembly of Republic of Macedonia, the President of Republic of Macedonia and the Judicial Council of Republic of Macedonia. The President and the Judicial Council propose two judges and the remaining 5 judges are proposed by the Commission for electing and appointing of the Assembly of Republic of Macedonia. The abovementioned constitutional solution enables all branches of the state power to participate in the election of the judges of the Constitutional court. The constitution maker determined that the judges are elected from the ranks of eminent lawyers.

Regarding the solution for the composition of the Constitutional court, in modern terms, two opposite standpoints prevail. The former that refers to the fact that the procedure for election of the judges of the Constitutional court secures evasion of the danger that the court would be an extension of a specific political group and the latter, that stresses that the mode of election of judges increases the political influence on the judges. In context of the first thesis, the most frequent argument is the fact that 2 authorities involved in the procedure for election (President and the Assembly) are political authorities and look after the political profile of the judges, while the Judicial Council for their competence. This

\footnotetext{
3 ibid

${ }^{4}$ Treneska-Deskoska Renata, Ustavniot Sud na Republika Makedonija - Dilemi i Perspektivi. Skopje. 2010. p.28.
} 
enables the composition of the court to reflect different political profiles and different legal professions. On the other hand, the second theoretical standpoint insists on the need of reduction of party influence and the need of expert qualifications for election of judges.

Nonetheless, if we cumulatively take into consideration the fact that the judges of the constitutional courts are not career judges and that the sole criteria for election is for them to be in the ranks of eminent lawyers (and not judges), the conclusion is imminent that it is impossible to evade the political and party criteria in the election.

\section{Functions of the Constitutional Court of Republic of Macedonia}

The Constitutional courts, as specialized organs out of the regular judiciary's system, have more functions. The solving of a large number of constitutional disputes is in their jurisdiction.

The Constitution maker of the Republic of Macedonia, through the method of enumeration, has strictly stated the jurisdiction of the Constitutional court. Article 110 provides that:

- decides on the conformity of laws with the Constitution and on the conformity of collective agreements and other regulations with the Constitution and laws;

- protects the freedoms and rights of the individual and citizen relating to the freedom of conviction, conscience, thought and public expression of thought, political association and activity as well as to the prohibition of discrimination among citizens on the ground of sex, race, religion or national, social or political affiliation;

- decides on conflicts of competency among holders of legislative, executive and judicial offices;

- decides on conflicts of competency among Republic bodies and units of local self-government;

- decides on the answerability of the President of the Republic;

- decides on the constitutionality of the programmes and statutes of political parties and associations of citizens; and

- decides on other issues determined by the Constitution.

The principle function of the constitutional court is the normative control of the general legal acts. The basis for this function is the Constitution.

The comparative constitutional experience shows that the subject of control of constitutionality (judicial review) may be: the constitutions of federal units, laws, international agreements and other legal acts (rules of procedure of legislative authorities, regional ordinances or decrees with the force of law). The Constitution of Republic of Macedonia affirms that the Constitutional court is competent to decide on the conformity of laws with the Constitution, on the conformity of the collective agreements and other regulations with the laws and the Constitution, in the framework of the normative control of constitutionality of law. The review of these acts is abstract and repressive. The dispute that is heard by the Constitutional court is one between to legal norms (the constitutional norm and the one of the act that is subject to review), and not between two legal subjects. The decisions of the Constitutional court are final and enforceable. They have an erga omnes effect and cannot be appealed.

The legal analysis of the constitutional solution that refers to the normative control of constitutionality of law, points to the conclusion that the constitution maker has not been consistent to the model of enumeration when the acts that may be subject of review were stated, but has used the term "other regulations (other acts)". The said term is too broad and refers to the acts of the units of self-government (statutes, decisions, conclusions of the municipal council), bylaws passed by the executive, acts of organizations and institutions that perform public authorizations, acts of educational, health and other institutions and so on. All of the above may be subject to constitutional review, but only if they are general legal acts i.e. if they affect an undetermined number of persons.

The question for the control of constitutionality of the international agreements raises questions at the Constitutional court. Namely, unlike systems that accept the "model of transformation" and which are facing the challenge to decide when to realize the procedure for constitutional review of international norms - when the process of ratification is finished and the international treaty becomes effective or in the previous phases of this procedure, the Constitutional court of Republic of Macedonia faces the dilemma if it is competent to review international agreements. Regarding this issue, the Constitutional court has been inconsistent. In 1996 the court has determined that the constitutional review of international agreements and treaties, is realized by the Assembly of Republic of Macedonia in the procedure for their 
ratification ${ }^{5}$, but five years later, in one of its decisions the court determines the possibility to review the formal and material constitutionality of the law for ratification of the international agreement, since it becomes part of the domestic legal order 6 .

The demand for harmonization and monolithism of the legal order imposes the need for specific conformity of the law for ratification with the Constitution. The Macedonian scholars stress the possibility of realization of preventive constitutional review of the international agreements similar to the examples of many countries and through continued practice of the court for filling the constitutional void.

\section{The Need for a Constitutional Complaint in Republic of Macedonia}

The Constitution provides for limited jurisdiction of the Constitutional Court to decide on protection of only a certain number of rights including: rights and freedoms of man and citizen relating to the freedom of conviction, conscience, thought and public expression of thought, political association and activity and the prohibition of discrimination on the basis of sex, race, religious, national, social or political affiliation? ${ }^{7}$. From the stated solution we get the impression that the basic intention of the ",founding fathers" of the Macedonian Constitution, was to focus the Constitutional Court on the control of the constitutionality and legality of general legal acts. By such regulation, the constitution maker has left the citizens without a possibility for protection of their rights and freedoms (except for the abovementioned) by the Constitutional Court, in circumstances where they are affected by individual legal acts and therefore took away the possibility of an additional mechanism for detection of unconstitutional legal acts in the system.

The Rules of Procedure of the Constitutional Court of the Republic of Macedonia in part IV under the title "Procedure for protecting the rights and freedoms of Article 110 paragraph 3 of the Constitution of the Republic of Macedonia"' or precisely through 7 Articles, determines the jurisdiction of the Constitutional Court concerning the protection certain rights and freedoms. The solutions of the Rules of Procedure provide that "every citizen who deems that an individual act or action violated a right or freedom set out in Article 110 paragraph 3 of the Constitution, may require protection by the Constitutional Court within 2 months from the date of delivery of the final or effective individual legal act, or from the day of learning of the taken action which made a breach, but not later than 5 years from the date of its taking "8. The said provision is important to be analyzed from two aspects : 1) The Constitutional Court manifested extremely restrictive approach to the protection of the already limited number of rights and freedoms, which is evident since the Rules of Procedure are limited to the term citizen, and not "human" as the Constitution provides, and 2) probably fearing the increased workload, the Court provides an additional instrument which proportionally increases the possibility of not to act upon such cases - subjective and objective deadline.

Further, the Rules of Procedure provide that in the application the reasons must be stated for which protection is sought, acts or activities by which the rights and freedoms have been violated, the facts and evidence on which the application is founded, and other information necessary for the decision of the Constitutional Court. The application shall be delivered for response to the authority that passed the individual act or the authority that took the action by which the rights and freedoms are violated, within 3 days of submission. The deadline for response is 15 days $^{9}$. The Constitutional Court decides upon the protection of human rights after a public hearing. The parties to the proceedings, the Ombudsman and if necessary other persons, bodies or organizations are summoned at the public hearing. A public hearing may be held even if one of the participants in the procedure or the Ombudsman is not present, but if properly summoned ${ }^{10}$. By the decision for protection of the freedoms and rights shall be determined whether there is a violation and based on that, the Court will overturn the act, prohibit the action that caused the violation or reject the application ${ }^{11}$. All of the above is also the reply to how far the Constitution and the Rules of Procedure have gone in terms of the usual definition of a constitutional complaint.

The experience of implementation of constitutional review in other countries that have accepted the above legal remedy determines that the biggest workload of constitutional courts and the largest percentage of decisions made by the

\footnotetext{
${ }^{5}$ U.no. $230 / 1996$

6 U.no. $140 / 2001$

7 The Constitution of Republic of Macedonia art.110-3

${ }^{8}$ The Rules of Procedure of The Constitutional Court art.51

9 The Rules of Procedure of The Constitutional Court art.53

10 The Rules of Procedure of The Constitutional Court art.55

11 The Rules of Procedure of The Constitutional Court art.56
} 
courts concern the procedures upon the instrument of constitutional complaint. That is not the case with the Republic of Macedonia. The Constitutional Court of the Republic of Macedonia receives relatively few applications for the protection of freedoms and rights, and statistics indicate that the Court mostly issues a decision for dismissal upon different grounds such as: lack of jurisdiction to decide on protecting the rights of that are not provided with the Constitution decides only when it comes to protecting one's own and not someone else's rights lack of jurisdiction to decide upon violation by an act that is not final or effective, lack of jurisdiction to decide upon the rights and interests of the party in a particular case For a small number of applications the Constitutional Court has decided in merito.

Finally, the question arises which elements have to be taken into consideration in case of extension of the jurisdiction of the Constitutional Court, through the introduction of the instrument constitutional appeal. In this context, the following issues should be considered:

- Scope of the rights that will be subject of protection under this instrument- Constitutional literature analyzes different solutions regarding the scope of the rights protected with the constitutional complaint.

1) The experience of Germany and normative solutions of recourso de amparo constitutional in Spain indicate that this instrument is modeled initially to ensure the protection of fundamental human rights and freedoms.

2) The Slovenian model on the other side does not provide a limitation of the rights that may be protected by the instrument of constitutional appeal. Therefore the subject of protection may not only be the rights and freedoms provided with the Constitution, but also the rights provided in the ratified and published international documents.

Finally, the system of control of constitutionality of acts of Republic of Macedonia will have to choose between these two alternatives. Of course, the solution will depend on the manner of arranging the issue of the entities authorized to initiate proceedings for constitutional control.

- Entities that shall have the right to initiate proceedings - In Slovenia the entities that may file a constitutional complaint at the Constitutional Court are all natural and legal persons and the Ombudsman. In Spain recourso de amparo constitutional may be submitted by all natural and legal persons as well, the Ombudsman and the Prosecutor General. It covers not only the citizens, but also the foreigners. In Germany the right to initiate proceedings covers all individuals with capacity to act and legal persons (even those legal persons that are not registered in the country). Regarding the subjects who have the right to initiate proceedings in Macedonia it must be emphasized the provision of the Rules of procedure - article 51 which points to the solution every "citizen" and not "everyone", which significantly limits the possibility for protection before the Constitutional Court of the rights provided in the Constitution. On the other hand, it should take into account the experiences of the countries that practice this instrument, and the right to constitutional complaint is tied to the legal entities and not just individuals. Finally it should be considered the Ombudsman to appear as an authorized entity who has the right to initiate proceedings.

- Acts against which this special remedy may be filed - The systems of control of the constitutionality and legality of legal acts classifies two basic methods in which this matter is regulated. One model predicts that the constitutional complaint may be filed to protect the rights violated by law, decisions, actions or legal acts of the organs of public authorities. These include decisions, laws and other legal acts of state bodies and the autonomous communities and all other Bodies and organizations which exercise public authority. The second model provides that this instrument may be filed for protection of rights that are violated by the decisions, actions or legal acts of the bodies of public authorities. These include the decisions, other legal acts and actions by state bodies and the autonomous communities and all other bodies and organizations which exercise public authority.

The normative solutions concerning the protection of freedoms and rights by the Constitutional Court in Republic of Macedonia should precisely regulate this issue. It should be noted whether the protection applies only to acts by which the rights are violated and are adopted by the state authorities, or to apply the Slovenian experience in which case it refers to rights that are violated by individual acts of state authorities, local self-government units or entities exercising public authorities. On the other hand, it should be considered between the alternative whether the said instrument could be submitted if the violation of rights is done by a law (and which additional conditions and restrictions would apply in this case) or the law as a general legal act will be excluded and the constitutional complaint would be restricted only to individual legal acts.

Finally, from all of the stated above it may be concluded that the need for additional instrument for the protection of rights and freedoms is never excluded and that if the powers of the Constitutional Court of the Republic of Macedonia are 
expanded, it should be considered to implement the constitutional complaint. It should be done with extreme care and only upon previous analysis of the normative solutions and experiences from countries that practice this instrument.

\section{Conclusion}

The modest constitutional provisions of the Constitution of Republic of Macedonia and the several specific constitutional solutions, have faced the Constitutional court with accusations of judicial activism on one hand and with skepticism in its capacity to pass decisions that would annul the unconstitutional legal provisions, on the other. Thus, it seems that the position and authority of the Court in the system is a logical consequence of two cumulative facts: the lack of specific engagement of the constitution maker and the inconsistent practice and the frequent lack of argumented and elaborated decisions of the court. However, it cannot be left out that the Constitutional court was confronted with the challenge to participate in the fundamental change of the legal system in Republic of Macedonia and the process of transformation of a state that is "dying out" to a legal state. Namely, it appears that the Constitutional court was equally involved in the modeling of the constitutional system of Republic of Macedonia just as the other state authorities, and it must be noted that it carried the burden of building a new legal system by interpretation of the constitutional provisions.

Today, the Constitutional court of Republic of Macedonia mainly confronts two completely opposite remarks. It leaves the impression that the constitutional court has not yet found the magical formula for deciding that manages to sustain the balance between the modest, non-intrusive and non-confrontational action of the constitutional courts and the extravagancy of the decisions which directly participates in the modeling of the constitutional order.

Thus, on one side, it is admonished to the Macedonian Constitutional court that it applies the so called passive virtue, that Bickel recommends for the methodology of deciding of the Supreme Court of the USA, in a completely different extremity. Namely, instead of a virtue, the deciding by the court is often qualified as fear, modesty or introversion. The argument that the Constitutional court restrains from initiation of procedures for control of constitutionality, probably due the fear of self-promotion and its qualifications as a co-legislator.

From a completely different perspective, the "guardian of the Macedonian Constitution" was qualified as an institution of the so called "ancient regime" and was subject of undervaluation, especially in the past several years. The Macedonian scholars have recognized such qualifications as elements of so called "political mobbing" realized through undervaluation and political labeling.

The only way out of this situation can be found in decisions that will be well argumented and elaborated. Only in this manner, by decisions that will hold the balance between the bold and the modest actions of the court, which shall have in their background the well grounded legal argumentation, the court may defend itself from the variations of pressures. Finally, only the consistent deciding by the Constitutional court, whose decisions would guide the constitutional provisions in the direction of protecting the civil rights and removal of the "pathology" of the system, may give the qualification of "lord of the resources of constitutional law" or "generator of contemporary ideas".

\section{References}

Bickel M Alexander. Least dangerous Branch The Supreme Court at the Bar of Politics.Yale University Press. London.1986.

Bilder , Mary Sarah. Idea or Practise A Brief Historiography of Judicial Review. The journal of policy history. vol20, No.1,2008

Bulajich Svetislava. Cuvar Frncuskog ustava. Sluzbeni glasnik.Beograd 2006.

Deskoska Renata. Konstitucionalizmot I Covekovite Prava. Skopje. 2006

Ginsburg,Tom. The Global spread of Constitutional review. Oxford Handbook of law and politics. 2008

Lipkin,Robert. What's Wrong With Judicial Supreamacy? What's Right About Judicial review?. Weudener Law School Legal Studies Research Paper Series no.08-85.

Marcus.Maeva. The Founding Fathers,Marbury vs Medison-And So what?. Constitutional justice under old constitutions.edited Smith Eivind. Kluwer Law International. The Hague Netheralnds.1995

Maus Didier. The Birth of Judicial Review of Legislation in France.The Hague.1995.

Mc Closkey, Robert G. The American Suprene Court, The Univeristy of Chicago Press, 2000.

Roermund van Bert. Constitutional Review-Theoretical and Comparative Perspectives. KluwerLaw and axation Publishers. Devenetr/Boston.1993

Siljanovska-Davkova. Gordana. Ustavniot Sud na Republika Makedonija od Moj Agol. Forum Europaeum. Ustavniot sud na Republika Makeodnija-status, dilemi i perspektivi. Skopje.2010

Tate,C. Neal. Comparative Judicial Review and Public Policy : Concepts and Overview. Greenwood press. London. 1992

Тренеска Дескоска Рената. Конституционализам. Скопје.2015 